\title{
Croatian accentual norm at the beginning of the 21st century (from theory to practice and back)'
}

Abstract: Croatian accentual norm is in a constant state of flux. Its stability is impeded, first of all, by two mutually intertwined forces: the nature of the accentual norm, which belongs to speech (dynamic dimension, individual realisation), and the disagreement amongst linguists as to what to record and prescribe (in constant interaction between the stress accent and pitch accent systems). The modern accentual norm is obtained from non-orthoepical manuals, i.e. grammar books, dictionaries, handbooks (which further complicates the clarification of the orthoepical reality). We will conduct a comparative analysis of the approach, in modern handbooks, to accent alternations in morphology, falling accent in non-initial syllables in word formation, post-tonic length, uncertainties regarding lexical stress, etc. Grammar books and dictionaries approach the open questions in different ways and this paper gives an overview of the (systematic and non-systematic) solutions offered by linguists today, with the aim of presenting the dynamics of the codified norm (which carries the label of being "conservative" and "hidebound"). The changes in the modern norm are compared then to usus occurrences, illustrated by a narrower speech corpus - the speech of actors. In their orthoepical research, linguists resort to the speech of radio and television presenters, linguists in specialised radio and television programmes, students of the Croatian language or phonetics, Croatian language teachers, etc., and, more recently, to the speech of actors reading audio books (MP3 files are available at www. lektire.skole.hr). Presenters, teachers and actors have always been perceived as quintessential competent speakers of the standard language, so close observation of their speech as one of the steps in the process of describing and prescribing is the basis of every orthoepical research. Since the modern speech/pronunciation (e-lektira, audio versions of school reading list books available online) has still not been analysed and valorised linguistically/orthoepically, and since it is available to those learning and listening to speech values in this type of material, the paper turns to the corpus with the intention of determining the basic features of pronunciation. Prose texts whose pronunciation has been analysed are those written in or translated into the standard language. Special attention has been given to accent (stress placement and stress shift) and to the prosodic word. Specific pronunciation traits (especially those related to the accentual norm) have been compared to those prescribed in handbooks. Finally, the accentual traits acknowledged by the modern conception of accentual norm and codification were clarified as well as those that are systematically ignored in modern prescription.

Keywords: codified norm, usus, accent, e-lektira (audio versions of school reading list books available online)

Parts of this paper were presented at the round table discussion held at the Speech Research conference organized by the Phonetics Department of the Zagreb Faculty of Humanities and Social Sciences in 2019.

This text is licenced with Creative Commons Attribution 4.0 International License. For details, 


\section{Introduction}

The framework of the codified norm cannot accommodate all the linguistic levels; the lexical norm typically evades it, and it is also too tight for all the speech realizations attempting to take the "privileged position" and become the speech which is binding on all the public speakers. Ever since the listing and prescribing started, accentuation has been evading the standardization authority boisterously, so it is logical to ask "whether everything can be standardized indeed, for example, accentuation" (Kalogjera 1998: 245)2.

If we consider the stages of linguistic planning, it is clear that the accentual norm is in its infancy. After the stress (dynamic) accent system had infiltrated the Croatian public area and spread by way of the media into the entire Croatian speaking area, it has been coexisting with the pitch accent system, growing stronger, intertwining with it and gaining prestige. ${ }^{3}$ We are witnessing again the inception of the very first stage the stage of the norm selection. The former stages of description, prescription and elaboration of the Croatian accentual norm have not been accepted precisely due to the wrong choices (best portrayed by the so-called Karadžić, Daničić-Maretić stage, followed by the so-called classic accent stage). The expansion, cultivation, valuation and upgrading of the Croatian accentual norm will not be possible as long as not only the majority of speakers, but also those who describe and prescribe it, are unconversant with the pronunciation norm ("the ideal we aspire to"). The fact that the accent is also a "paralinguistic sign" (Škarić - Lazić 2002: 7), a speech marker which "marks" the speaker, additionally complicates the situation.

For any new or fresh considerations and deliberations of a solution, we must stop in the present moment and analyse the status of the accentual norm in modern normative handbooks, study carefully

\footnotetext{
"može li se baš sve normirati, npr. akcentuacija" (Kalogjera 1998: 245).

"However, irrespective of the official standard accent, since Zagreb is the capital, it is interesting that, for example, nowadays, the Zagreb accent enjoys the same level of prestige as the standard accent in Croatian language..." ("No bez obzira na službeni standardni naglasak, s obzirom na to da je Zagreb glavni grad, zanimljivo je npr. da zagrebački naglasak danas u hrvatskom ima paralelni prestiž uz standardni naglasak...") (Kapović 2010b: 67).
} 
what is being written about it and how. Numerous unresolved issues regarding the accentual norm, its status and lack of foundation during the $20^{\text {th }}$ century can still be found in the scientific texts that are still probing into it. Vague assessments of its status are so common that we can still hear generalized statements, such as "the accentual norm is in a state of chaos", "the classical, Maretić norm is the prescribed one", "the accent is rural and archaic", "handbooks prescribe pronunciation based on linguistic concepts", etc.

All of this has encouraged us to once again browse the most recent handbooks, dive deeper into them and search for any novelties that are not in accordance with the usus. A comparative analysis has been conducted of contemporary grammar books, dictionaries and handbooks (from the early $20^{\text {th }}$ century up to this day) and the speech commonly used by actors in audio recordings of books from school reading lists on e-lektira web sites (www.lektire.skola.hr) as an illustrative example of how some of the educated and competent speakers actually speak.

\section{The accentual norm at the beginning of the $21^{\text {st }}$ century}

The analysis of the accentual norm from contemporary handbooks is focused on three basic facts: the relationship towards defined distribution rules, the relationship toward stress shift, and the stance on post-tonic lengths. Since the classical accentual norm was strict and required the rules ${ }^{4}$ to be abided by (almost) without exception, it is completely logical to turn to those basic presumptions, as far as the pitch accent system is concerned.

4 Brabec-Hraste-Živković's Grammar of Croato-Serbian Language (Gramatika hrvatskosrpskoga jezika) made no mention of any exceptions to the rule of stress placement in a word, but it did note the following regarding the stress shift: "It can often be seen in literary texts that the accent is increasingly less often transferred to the proclisis, especially to polysyllabic prepositions and conjunctions: preko môra instead of prëko mōra, u jëzeru instead of ù jezeru, ni brätu instead of nì bratu, kad rëčèm instead of kàd rečém, da vï̀ìm instead of dà vidìm, dâni i gödine instead of dâni ì godine." ("U književnom se jeziku opaža sklonost da se akcent sve rjeđe prenosi na proklitiku, naročito na višesložne prijedloge i na veznike preko môra mjesto prëko mōra, u jëzeru mjesto ù jezeru, ni brätu mjesto nì bratu, kad rëčèm mjesto kàd rečèm, da vïdìm mjesto dà vidìm, dâni i gödine mjesto dâni ì godine.") (1966: 21) 
Nowadays, it is completely normal to find remarks such as the following in contemporary grammar books: ${ }^{5}$

Accent distribution in Croatian standard language sometimes deviates from the rules. These deviations refer to falling accents on non-initial syllables. Words with such distribution of falling accents can be accepted as accent doublets (sometimes event triplets) which are often more common than the words with accentual properties that comply with the systematic accentuation norm. (HG 2005: 70) ${ }^{6}$

The functional-stylistic stratification of the linguistic reality is presented as the solution to any doubts. The entire Croatian Grammar Book (Hrvatska gramatika) by E. Barić and a group of authors ${ }^{7}$ is based on polarizing examples in functional (including temporal) stratification: spoken ${ }^{8}$ language vs. higher variety. In addition to the settled

5 Because school grammar books prefer unambiguous solutions, it is unlikely that they will contain many notes on the functional stratification of standard pronunciation. When it comes to accentuation rules, Težak-Babić's Croatian Language Grammar BookHandbook for Basic Linguistic Education (Gramatika hrvatskoga jezika - priručnik za osnovno jezično obrazovanje) only mentions the exception from the rule that the last syllable in interjections cannot be accented (2000: 83). The School Grammar Book of Croatian Language (Školska gramatika hrvatskoga jezika) by S. Ham presents a few cases of falling tone on a non-initial syllable (2017: 28). By the way, this grammar book contains numerous errors in marking accents and lengths. The Croatian School Grammar (Hrvatska školska gramatika) issued by the Institute for Croatian Language and Linguistics (www.gramatika.hr) makes no mention whatsoever of any exceptions from the distribution rules. Each of these three grammar books says that the accent "can shift" / "can be transferred" onto the proclitic.

6 "Od pravila o raspodjeli naglasaka u hrvatskom književnom jeziku ponekad se odstupa. Ta se odstupanja odnose na silazne naglaske u nepočetnom slogu riječi. Riječi s takvom raspodjelom silaznih naglasaka mogu se prihvatiti kao naglasne dublete (ponekad i triplete) i često su i običnije nego riječi s naglasnim svojstvima koja su u skladu sa sustavnom naglasnom normom." (HG 2005: 70)

7 This grammar book was preceded by the Institute's Croatian Literary Language Grammar Handbook (Priručna gramatika hrvatskoga književnog jezika) from 1979, republished in 1990 as the Croatian Literary Language Grammar Book (Gramatika hrvatskoga književnog jezika) and in 1995 as the Croatian Grammar Book (Hrvatska gramatika). The earliest editions, as expected, make no mention of the distribution rules in usus, but instead set forth the rules as to how to adapt borrowed words to the Croatian accent system (1979: 39).

8 Such polarizations often leave the definition of "spoken language" unclear - whether it is a style within the standard language or a spoken language which does not belong to the standard but to language as a system. Since grammar books note that something is frequently used in administrative or literary art jargon, we can also consider spoken language to be a style within the framework of the standard, which also means that it can be regarded as usus. In his work, Silić included usus, norm and codified norm under an umbrella term: the standard. 
(accentual and morphological) paradigms, it mentions the following: celulit - celulita, asistënt - asistènta, ${ }^{9}$ and that asistent - asistenta is also possible (2005: 139) or make remarks such as: "People usually say sakö, ragü, and less often sakô, ragû." (2005: 139). ${ }^{10}$

Practical Croatian Grammar Book (Praktična hrvatska gramatika) by D. Raguž was one of the first attempts to describe the places in the system that are defied by the usus (Intonation and Accent chapter). The approach to the revision of distribution rules was somewhat more open here: "In the standard language, deviations are most frequent in foreign words and compounds." (PHG 1997: 446), ${ }^{11}$ whereas the stress shift was approached with more doubt and reservation: "Deviations, which are extremely rare, are perceived as a violation of the accentual norm when it comes to one- and two-syllable words." (PHG 1997: 451); " "The transfer obviously often does not occur, but the linguistic (accentual) norm is clearly trying to find it, as a matter of principle." (PHG 1997: 452). ${ }^{13}$ The description includes many "exceptions to the exception", so the peculiarities of spoken language (lapidârij, alumînij, koeficijënt, kupoprödaja, milostîva, etc.) are distinguished from "grave accentual errors" (komunïst, budïst, zadâtākā, etc.), and even from "accentual errors graver than others" (zadâtākā is a "graver error" than izuzêtākā). Such a system of exceptions to the rule (that comes down to certain suffixes, the time when some borrowing was made or the number of syllables in a word) is not always founded on fact, or logical, and as such it presents a challenge for a lay person.

In Word Formation (Tvorba riječi) (2002), Stjepan Babić scrutinized the rules and found those that would come close to the usus, and concluded that is, in fact, "the author and his linguistic sentiment"

9 This accentual paradigm is questionable because common use confirms either the forms found in common use are studënt - studënta or stùdent - stùdenta (or on the first syllable and with a dynamic accent in those speakers who come close to the standard in terms of stress placement, but not tone).

10 "Govori se obično sakö, ragü, rjeđe sakô, ragû." (2005: 139).

11 "U standardnome jeziku odstupanja su najčešća u stranim riječima i u složenicama." (PHG 1997: 446)

12 "Odstupanja obično nema i doživljavaju se kao kršenje naglasne norme ako je riječ o domaćim jednosložnim i dvosložnim riječima.” (PHG 1997: 451)

13 "Očito je da toga prijenosa često nema, ali da ga jezična (naglasna) norma načelno traži." (PHG 1997: 452) 
that were (and are) the main methodological principle in the creation of the accentual norm:

Most accent data can be found in dictionaries, but the problem is that many of the more recent dictionaries transfer the accents from older dictionaries without any scrutiny whatsoever. (...) To prevent these words from sounding as if the state of things in terms of accent was completely chaotic, we must stress that, despite such a state, certain accentual rules could always be ascertained because more recent dictionaries present more doublets and therefore more choices, I partially corrected different kinds of data using my own linguistic sentiment (bolding by B. M.), and a large number of examples mostly demonstrate systematic relationships in that area as well. (TR, 2002: 19) $)^{14}$

TR contains a number of examples such as: poljoprìvreda, samoöbrana, samoöbmana, samoïzdaja, samospöznaja, samozâštita, superrâdnīk, superpüška, minisüknja, telekämera, kvazipjësnīk, aerosjëtva, agromäksimum, sjeverozâpad, kupoprödaja, vodoprïvreda, etc., or in doublets: cirkusijänt, cirkusänt, muzikänt, politikänt, bubänt, etc. ${ }^{15}$

The first part of the Academy's grammar book (PPO and GOHKJ), the chapter on morphology, albeit with a bit more reservation, says: "in spoken language, in loanwords such as kompòzìtor, kòmpjūtor, sënätor, the Neo-Štokavian accent system is disrupted and the stress does not move to the previous syllable and leaving the LF (long-falling) on the central syllable: kompozitor, kompozitora, kompozitoru." (2002: 312; 2007: 312). ${ }^{16}$ On the other hand, the chapter

14 "Najviše se naglasnih podataka nalazi u rječnicima, ali je teškoća u tome što mnogi noviji rječnici nekritički prenose naglaske iz starijih. (...) Da se iz tih riječi ne bi dobio dojam kako je naše naglasno stanje potpuno kaotično, valja naglasiti da su se unatoč takvu stanju često mogle utvrditi sasvim određene naglasne zakonitosti jer noviji rječnici donose više dubleta pa se moglo birati, raznovrsne sam podatke djelomično korigirao svojim jezičnim osjećajem, a velik broj primjera uglavnom je jasno pokazao sustavne odnose i na tom području." (TR, 2002: 19)

15 In the first volume of the grammar book issued by the Academy, other authors argue for the following: küpoprodaja, mäloprodaja, sämoobmana, sämoobrana, sämouprava, špekùlant, trafikant, etc. (GOHKJ 2007)

16 "u razgovornom jeziku u posuđenica tipa kompòzītor, kòmpjūtor, sènātor narušava se novoštokavski naglasni sustav pa se naglasak ne pomiče na prethodni slog i ne mijenja ton te DS ostaje na središnjem slogu: kompozîtor, kompozîtora, kompozîtoru." (2002: 312; 2007: 312) 
on phonetics by I. Škarić, moved in a completely opposite direction from the presentation of the accent system as described by the other parts of the same edition - "the general Croatian language" is considered through the prism of three types: the classical one (where the falling accent is found exclusively in the first syllable), the acceptable one (a compromise whereby the place of the stress is classic, yet with many exceptions) and the accepted one (where the place of stress, which is dynamic in this case, is optional). Škarić prefers the accepted, hybrid type which, in the author's opinion, is used "by persons of culture, politicians, in the field of economy, in schools, by reporters and in other public areas", and whose inventory can include a varying number of accents, ranging from one to five (GOHKJ 2007: 125).

Taking a page from Škarićs ideas on the permeability of classic distribution rules and largely resembling his description of the so-called acceptable type, the fourth volume of the Academy's Grammar Book was compiled (although partly non-systematically). Its authors (S. Vukušić and I. Zoričić) belong to the so-called Pula accentological school whose ideas (as presented by others) are quite often (but not always and without reasoning) confronted with the ideas of some other "accentological school".

Silić-Pranjkovićs grammar book confronted the "classic Croatian standard language" with some Western Štokavian idioms, which underlie the standard, and the spoken style:

In some parts of Western Štokavian idioms which underlie the Croatian standard language, falling accents also occur on the non-initial and therefore on the final syllable as well. Cf.: organizâtor, relïkt, defëkt, subjëkt, asistënt, kontinënt, etc. The Croatian standard language, particularly its conversational style, has been accepting such accents as correct. (SP 2005: 20) $)^{17}$

"U nekim se područjima zapadnoštokavskih govora, koji su u osnovici hrvatskoga standardnog jezika, pojavljuju silazni naglasci i na neprvome, pa onda i na zadnjemu slogu. Usp.: organizâtor, relïkt, defëkt, subjëkt, asistënt, kontinënt itd. Takve naglaske hrvatski standardni jezik, posebno njegov razgovorni stil, počinje primati kao pravilne." (SP, 2005: 20) 


\section{KNJIŽEVNI JEZIK 31, 2020. (115-149]}

They note additionally that: "We would allow such accents (for now) only in the conversational style." (SP 2005: 171). ${ }^{18}$ This grammar book also takes a communicational approach in the explanation of the post-tonic length and the stress shift: the length is both spoken and not spoken, and the accent is both transferred and not transferred (SP 2005: 20-21), which is the biggest step toward communication (even though this is a grammar book - a handbook which, as a model presentation, departs from it the most).

When it comes to word formation, the contemporary grammar norm warns of the falling accent on a non-initial syllable in compounds, when it comes to morphology, it reveals a new accentual paradigm limited to loanwords, and when it comes to prosody, it draws attention to the static nature of the stress in the proclisis.

Table 1: The falling accent on a non-initial syllable in certain categories in contemporary grammar books

\begin{tabular}{|c|c|c|c|c|c|}
\hline TR & GOHKJ & NHKJ & HG & PHG & SP-GHJ \\
\hline $\begin{array}{l}\text { poljoprïvreda } \\
\text { samoöbrana }\end{array}$ & $\begin{array}{l}\text { küpoprodaja } \\
\text { sämoobrana }\end{array}$ & $\begin{array}{l}\text { poljoprïvreda } \\
\text { sämoobrana, } \\
\text { samoòbrana, } \\
\text { samoöbrana } \\
\text { (conv.) }\end{array}$ & $\begin{array}{l}\text { poljoprìvreda } \\
\text { (poljòprivreda, } \\
\text { poljoprìvreda) }\end{array}$ & $\begin{array}{l}\text { poljoprîvreda } \\
\text { kupoprödaja } \\
\text { primoprëdaja } \\
\text { jugozâpad }\end{array}$ & $\begin{array}{l}\text { maloprödaja } \\
\text { poluïstina } \\
\text { desetomjësečnī } \\
\text { imovinskoprâvnī }\end{array}$ \\
\hline $\begin{array}{l}\text { muzikant i } \\
\text { muzikänt }\end{array}$ & $\begin{array}{l}\text { dirìgent and } \\
\text { dirigënt }\end{array}$ & $\begin{array}{l}\text { asistent, } \\
\text { asistënt } \\
\text { (conv.) }\end{array}$ & $\begin{array}{l}\text { asìstent and } \\
\text { asistënt }\end{array}$ & $\begin{array}{l}\text { dirìgent and } \\
\text { dirigënt }\end{array}$ & $\begin{array}{l}\text { asìstent and } \\
\text { asistënt }\end{array}$ \\
\hline
\end{tabular}

Škarić, Vukušić, Zoričić, Babić, Silić and Pranjković - were all in favour of a revision of distribution rules and a description of the accentual norm in its functional stratification. Every contemporary grammar book (whose authors include the above-mentioned linguists) mentions the falling accent on the contexts in which this is a non-initial syllable (including the stress shift), describes the places where this is a common occurrence (e.g. in compounds, loanwords

18 “Takve bismo naglaske mi (zasad) dopustili samo u razgovornome stilu.” (SP, 2005: 171) 
and foreign names, in certain cases (nouns in the vocative case, singular, and in the genitive case, plural), within prosodic words including proclisis, in interjections, in the pronunciation of abbreviations) and exemplifies this by doublets.

When notes on the usus make it into a grammar book, this seems to be the first step towards the re-standardization of the accentual norm. It is particularly interesting that in Croatian contemporary linguistics, prescription is more frequent in dictionaries than in grammar books, even though dictionaries from the beginning of this century (of the above-mentioned authors, HER and NHKJ) seemed to draw closer to the usus and the settled solutions generated by the speaking community. However, the accentual norm in dictionaries has recently taken a step back by insisting on the "principle of systematic structure" which is fitted to the principle of authority and complete autonomy, and which exalts again the accentual norm, speech and pronunciation toward the ideal which, although aspired to, is rarely approximated.

Table 2: The falling accent on a non-initial syllable in certain categories in contemporary dictionaries ${ }^{19}$

\begin{tabular}{|c|c|c|c|c|c|}
\hline VA-RHJ & RHJ-LZ & $\begin{array}{l}\text { HER; HJP; } \\
\text { VA-ŠRH }^{20}\end{array}$ & NHKJ & ŠRHJ; HJS & VRH \\
\hline poljoprìvreda & poljoprivreda & $\begin{array}{l}\text { poljoprivreda } \\
\text { (poljoprïvreda) }\end{array}$ & poljoprïvreda & poljoprivreda & poljoprìvreda \\
\hline primoprèdaja & primoprèdaja & primoprèdaja & primoprëdaja & primoprèdaja & primoprèdaja \\
\hline samoòbrana & $\begin{array}{l}\text { sämoobrana } \\
\text { (samoòbrana) }\end{array}$ & samoòbrana & $\begin{array}{l}\text { sämoobrana, } \\
\text { samoòbrana, } \\
\text { samoöbrana (conv.) }\end{array}$ & $\begin{array}{l}\text { samoòbrana; } \\
\text { sämoobrana }\end{array}$ & samoòbrana \\
\hline rimokàtolik & rimokàtolik & $\begin{array}{l}\text { rimokàtolik } \\
\text { (rimokätolik) }\end{array}$ & $\begin{array}{l}\text { rimokàtolik, } \\
\text { rimokätolik (conv.) }\end{array}$ & rimokàtolik & rimokàtolik \\
\hline rimokàtoličkī & rimokàtoličkī & rimokàtoličkī & rimokätoličkī & rimokàtoličkī & rimokàtoličkī \\
\hline
\end{tabular}

19 Other handbooks can also be classified under this category. For example, NHKJ is the fourth volume of the so-called the Academy's Grammar, but since a large part of it is a dictionary, we can also regard it as a list of words. The same applies to the HJS's handbook.

20 Anić's School Dictionary (Školski rječnik) was prepared by I. Pranjković and L. Badurina. Pranjković also did the accent-marking in HER. In this dictionary, the Croatian word for "man" was accentuated as čövjek (which was subsequently explained as the result of a stress shift: the added prefix causes a transfer of the accent: nëčovjek, but the negation can receive a short falling accent on the initial syllable for the sake of expression as well, not necessarily due to the transfer of the falling accent), and the same is mentioned in VA-ŠRHJ, although Anić argued for čòvjek. 


\begin{tabular}{|l|l|l|l|l|l|}
\hline VA-RHJ & RHJ-LZ & $\begin{array}{l}\text { HER; HJP; } \\
\text { VA-ŠRH }^{20}\end{array}$ & NHKJ & ŠRHJ;HIS & VRH \\
\hline cirkùsant & cirkùsant & $\begin{array}{l}\text { cirkùsant } \\
\text { (cirkusänt) }\end{array}$ & cirkùsant & cirkùsant & cirkùsant \\
\hline asistent & asìstent & $\begin{array}{l}\text { asìstent } \\
\text { (asistènt) }\end{array}$ & $\begin{array}{l}\text { asìstent, asistënt } \\
\text { (conv.) }\end{array}$ & asistent & asìstent \\
\hline stùdent & stùdent & stùdent & stùdent & stùdent & stùdent \\
\hline sociòlog & sociòlog & sociòlog & $\begin{array}{l}\text { sociòlog, sociolög } \\
\text { (conv.) }\end{array}$ & sociòlog & sociòlog \\
\hline $\begin{array}{l}\text { rokòkō } \\
\text { (rokokô) }\end{array}$ & rokòkō & rokokô & - & rokòkō & rokòkō \\
\hline
\end{tabular}

After a number of comparative analyses and papers focusing on usage and frequency, this introductory note from VRH seems even more questionable: "Following the developmental tendencies of Western Štokavian accentuation leading to the simplification and unburdening of the accent system, when faced with the choice between the codified and practical accentuation, an advantage was given to the Croatian Western Štokavian usus norm." ${ }^{21}$ HJS, which adopted the "Western Štokavian accentuation", explicitly states the following in its introduction: "There are no falling accents on non-initial syllables in the Croatian standard language..." (HJS 1999: 71). ${ }^{22}$ It was believed that their approval in this regard would "endanger the accent system as a whole because falling accents in the speech practice of 'cultivated' and 'educated' speakers are not confined to some loanwords, but are in fact present in the overall cultural and civilizational lexical layer, in all the so-called Europeanisms (...) and in native words and forms..." (HJS, 1999: 71-72) ${ }^{23}$ If falling accents on non-initial syllables are "abnormal", to claim that they are so common in speech

21 "Slijedeći razvojne tendencije zapadnoštokavskoga naglašavanja, koje vode pojednostavnjivanju i rasterećenju naglasnoga sustava, u izboru se između kodificiranoga i uporabnoga naglaska prednost davala hrvatskoj zapadnoštokavskoj uporabnoj normi." (VRH, Introduction)

22 "Nema silaznih naglasaka na nepočetnim slogovima $u$ hrvatskome standardnom jeziku..." (HJS 1999: 71)

23 "ugrozilo naglasni sustav u cjelini jer silazni naglasci u govornoj praksi 'kultiviranih' i 'učenih' govornika nisu ograničeni samo na neke posuđenice, nego se ostvaruju u cjelokupnome kulturnom i civilizacijskom leksičkom sloju, u svim tzv. europeizmima (...) i u domaćim riječima i oblicima...” (HJS 1999: 71-72) 
practice is fairly unusual, to say the least. Relying only on the principle of systemicity, we remain in the realm of language as a system, whereas language as a standard also requires considering the principle of standardization and the principle of purposefulness, as well as the principle of being wide-spread and accepted - the standard as a multifunctional idiom can only be demonstrated in the interaction of principles. HJS linked the falling accent to conversational style: "A falling accent on non-initial syllables is characteristic of the conversational style." (HJS 1999: 73), ${ }^{24}$ but failed to explain whether this style is a part of Croatian language or of the standard language. If it is a matter of language style, then the remark is superfluous because in that case many options are "possible", and if it is a matter of standard language style, then the first claim that there is no falling accent on the non-initial syllable in the standard language is inherently contradictory.

Through all this, sight was lost of the flexible stability of the standard which resolves the tension between codification and usus in the linguistic community and stabilizes it by bringing closer and adjusting the (codified) norm to the usus, and not vice versa. In the 1960s, Jonke established the following for the words poljoprïvreda, samoüprava, primoprëdaja:

Although the position of the short falling accent on a middle syllable of those words defies the basic rule for the position of the short falling accent in general, our linguistic sentiment rebels against the shift of the accent one syllable to the front (samoùprava, primoprèdaje). Precedents to justifying such an impulse can be found in some popular compounds of the "Vuk type", such as ranoränilac, kojekäko, zlomï̌ljenīk and so on. (Jonke 1965: 233-234), ${ }^{25}$

24 “Silazno naglašivanje nepočetnih slogova obilježjem je razgovornoga stila." (HJS 1999: 73)

25 "Premda se položaj kratkosilaznoga akcenta na srednjem slogu tih riječi protivi osnovnom pravilu o položaju kratkosilaznog akcenta uopće, ipak se naše jezično osjećanje buni protiv prenošenja akcenta za jedan slog naprijed (samoùprava, primoprèdaja), a presedani za opravdanost takve pobude nalaze se i u nekim narodnim složenicama vukovskoga tipa, kao što je npr. ranoränilac, kojekäko, zlomišljenīk i sl.” (Jonke 1965: 233-234) 
Anić supported him in this sense (in the article On an accentuation process in various functions of the standard language $\left.{ }^{26}\right),{ }^{27}$ but not in the dictionary; the most recent dictionaries demonstrate no such shift.

According to the accent in the intermediary languages or the languages these words originate from, the short falling accent has become common in the conversational language of the educated circles: atlëtika - atlëtikē, akadëmik - akadëmika, arhaïzam arhaïzma. Although this accent is not codified because it opposes the rule that the medial syllable cannot bear a falling accent, it is accepted as correct in the practical spoken standard language as well as in mass media (radio and TV). (Anić 2009 (1975): 270) ) $^{28}$

Speaking of the pragmatism of the falling accent, he contends the following:

The " accent is most appropriate to serve here (in the examples marionëta, cirkusäntkinja and cirkusänt, note by B. M.) an informative purpose precisely within the meaning of the text, without any additional information on the origin and regional affiliation. Unlike the classic accent, it does not burden the fragile word "cirkusäntkinja" which conveys disdain and negative affection. (Anić 2009 (1968): 250) ${ }^{29}$

Intimations of such ideas could be found at the beginning of the century in HER which turns to the so-called "continental type" of accentuation and respects the then-current distribution rules only in principle: "... the metatonic accents as in poljoprivreda, samoùprava, samozáśtita, jugozápad, rimokàtolik are not considered realistic in

26 Ojednom akcenatskom procesu u različitim službama književnog jezika

27 The open issues regarding the falling tone on the non-initial syllable have been brought to the fore since the 1950s, starting with Kuzma Moskatelo.

28 "Prema akcentu u jezicima posrednicima ili jezicima iz kojih ove riječi potječu ovdje se ustaljuje u razgovornom jeziku obrazovanih krugova kratki silazni akcenat: altlëtika - atlëtike , akadëmik - akadëmika, arhaïzam - arhaïzma. Iako se taj akcenat ne kodificira, jer se kosi s pravilom da na unutrašnjem slogu ne može stajati silazni akcenat, u praktičnom govorenom književnom jeziku prihvaća se kao korektan i u sredstvima masovnih komunikacija (na radiju i na televiziji)." (Anić 2009 (1975): 270)

29 "Akcenat " najpodesniji je da tu (u primjerima marionëta, cirkusäntkinja i cirkusänt, op. B. M.) djeluje obavijesno, upravo u smislu teksta, bez ikakve dodatne informacije o podrijetlu i regionalnoj pripadnosti; on ne opterećuje težinom klasike krhku riječ cirkusäntkinja, semantički i kontekstualno punu prezrive afektivne boje.” (Anić 2009 (1968): 250) 
these examples, and are therefore not even mentioned." (HER 2002: $\mathrm{XV}) \cdot{ }^{30}$ Some of the accent forms (e.g. G pl. podâtākā, sveučilištârācā and so on) were not judged as incorrect, but still remained unlisted in the dictionary (which can be partially justified by the limited space which, we believe, can now be resolved with online dictionary editions). The falling accents are considered regional in verbs (namëtnēm, nastûpām) and in the sub-type àà-aáa (pjevấč, balôn).

In his article For the democratization of the Croatian orthoepic norm, ${ }^{31}$ Ivo Pranjković explains why the prescribed rules are departed from:

In using the standard language, the so-called peripheral Štokavians (Brozović also calls them by this name) and non-Štokavians have obviously started to perceive the Neo-Štokavian (central) accent system, with frequent and consistent shifts of stress toward the beginning of the word and with numerous post-tonic lengths, as characteristic of "extreme Štokavianism", i.e. as a regional, rural or even (especially in the recent years) Serbian accentuation type. (Pranjković 2010: 19) ${ }^{32}$

Taking into consideration all of the above, we can conclude that the rules of accent distribution in the Neo-Štokavian vernacular (particularly the one Brozović refers to as "central") certainly do not correspond to the accent distribution rules of the Croatian standard language today. (Pranjković 2010: 22) ${ }^{33}$

$\overline{30}$ “(...) ne smatraju se u ovakvim primjerima realnima metatonirani naglasci tipa poljoprivreda, samoùprava, samozáśtita, jugozápad, rimokàtolik pa se i ne navode." (HER 2002: XV)

31 Za demokratizaciju hrvatske ortoepske norme

In this article, Pranjković presents the thesis that accent shifts are more frequent in common words or those adopted long ago (ràsist, rèlikt, rèmont and so on), and that the falling accent on the last syllable is more frequent in newer words (reprïnt, resürs, retüš and so on). It seems, nevertheless, that the predominance of the falling tone is connected to word-forming suffixes, the number of syllables in a word, in addition to usage frequency and lexeme constancy. Doubts, if any, appear in case of two-syllable, or less often three-syllable words, and if the accent has already become common due to its frequent use in public communication (stùdent : studënt, rezìmē : rezimê).

32 "Očito je da su u služenju standardnim jezikom tzv. periferni štokavci (kako ih također naziva Brozović) i neštokavci dosljedni novoštokavski (centralni) naglasni sustav, s vrlo čestim i dosljednim prebacivanjima naglasaka prema početku riječi te brojnim zanaglasnim dužinama, počeli doživljavati kao osobitost 'skrajnje štokavštine' odnosno regionalnoga, ruralnoga, pa možda čak (posebno posljednjih godina) i srpskoga tipa naglašavanja.” (Pranjković 2010: 19)

33 "Na osnovi rečenoga može se zaključiti da naglasna distribucijska pravila novoštokavskoga narječja (posebice onoga koje Brozović zove 'centralnim') danas posve izvjesno nisu jednaka naglasnim distribucijskim hrvatskoga standardnog jezika.” (Pranjković 2010: 22) 
Vukušić, who often wrote in favour of the more conservative branches, was also inclined toward welcoming doublets, just as Pranjković and Silić were, and thus contributed to the stabilization of the orthoepic norm. What Pranjković saw as the biggest problem with this (the most conservative) norm those who insisted on the so-called classic ("the Maretić") norm which most speakers are so unversed in that they in fact acquire it as a foreign one.

At the end of the $20^{\text {th }}$ century, other branches also appeared, such as those that were in favour of the so-called urban accentuation (Škarić, Škavić, Varošanec Škarić) as well as those that used to promote certain idioms (Neo-Štokavian Ikavian with the idioms developing in the same direction) to the level of the standard (Vukušić).

At the turn of the century, in 1999, the Croatian Language Handbook (Hrvatski jezični savjetnik) appeared with an abundance of dualities, announcing a new era for the accentual norm. Even though this Handbook also argues against a falling accent on a non-initial syllable (with many instances of metatony), the novelty it brings is that it takes into consideration the multifunctionality of the standard and foreshadows future descriptions that include numerous doublets. ${ }^{34}$

Today, we can talk about three branches of linguists who are focused on studying the accentual norm (taking a somewhat different stance toward open issues from those that were active in the late $20^{\text {th }}$ century norm ${ }^{35}$ ): the conservative one - reluctant to change the distribution rules (the concept was realized in the most recent editions of

34 In the introductory chapters of HJS (1999: 75), its authors indicate that they wish to minimize the accentual dualities in future editions. However, that would be the wrong path to take because the stratification of the standard happens exactly in the direction of the doublets which need to be described and attributed to the variety/style/discourse type.

35 Samardžija (1999) mentions three prosodic norm concepts: 1. the traditional concept which strives for as few changes to the classic norm as possible; 2. the concept which advocates a transformation toward the situation in Western Stokavian idioms and 3. the one that exalts the characteristics of urban idioms. Škaric (2006) mentions the following three main branches: "Crypto-Yugoslavs", who advocate the "Croato-Serbian language"; "conservatives", who think the standard language has already been firmly established; and the "revolutionaries", who think the as-is standard is far from the natural optimum. Brozović (2005) writes about the following four branches: 1. accepting the classic Maretić norm (no serious supporters), 2. not rejecting the tradition, but replacing Eastern-Štokavian features with Western-Štokavian ones (which he himself is inclined toward), 3. accepting the peripheral Croatian dialect with a Western-Štokavian accent, Ikavian exclusively (S. Vukušić), 4. accepting urban idiom as the norm (I. Škarić, Đ. Škavić, G. Varošanec-Škarić). 
dictionaries), the moderate one - correcting accentuation rules in one part of the system (the concept was implemented in contemporary grammar books, for example) and the revolutionary one - bringing into question the entire accent system and taking into consideration both the dynamic and pitch accents and regarding the norm through the prism of variety (at present, detectable in scientific papers).

We have been treading new paths in the $21^{\text {st }}$ century, which resulted in our perspective shifting from the horizontal to the vertical stratification and the accent systems: pitch accent and stress accent systems, or both of these intertwined. Contemporary handbooks testify to the fact that there are no more followers of the classic norm which dominated in the $20^{\text {th }}$ century, nor anybody who would openly advocate solutions from organic idioms, and it is also obvious that the idioms of urban environments cannot be used as a model. From such perspectives, it seems less convincing to speak even today of the norm as "a given maximum norm" which is never realized "in its full scope", as, for example, Delaš (2006), Mićanović (2006), Kapović (2010) do.

Mićanović views the standard as an idiom which is "codified, supraregional in terms of reach and applicability, used primarily in institutional contexts and official communication. In 'everyday speech', it is never manifested in its ideal codified norm" (Mićanović 2006: 16-17). ${ }^{36}$ Kapović shares this view:

(...) the standard accent system with its tonal accent - i.e. falling and rising accents as well as stressed and unstressed lengths, is quite complicated in itself, and it is practically impossible for non-native Štokavians or those who are not professional speakers to master it. The Croatian standard accent is more of an ideal than a system each Croatian speaker will adopt. (Kapović 2010b: 72-73) ${ }^{37}$

36 “(...) kodificiran, nadregionalan s obzirom na doseg i valjanost, koristi se prvenstveno u institucionalnim kontekstima i službenim komunikacijskim situacijama, a u 'svakodnevnom jeziku' nikada se ne ostvaruje u svojoj idealnoj kodificiranoj normi." (Mićanović 2006: 16-17)

37 “(...) sâm je standardni naglasni sustav, s tonskim naglaskom - tj. silaznim i uzlaznim naglascima, i naglašenim i nenaglašenim duljinama, prilično kompliciran te ga je praktički i nemoguće usvojiti onima koji nisu izvorni štokavci ili profesionalni govornici. Hrvatski standardni naglasak je zapravo više ideal, nego što je sustav koji će svaki govornik hrvatskoga usvojiti." (Kapović 2010b: 72-73) 
In another place (speaking of accentuation as "the more obscure part of the standard") he points to what we do not have - an official form of language "which will, in general, serve as a reasonably neutral means of communication" (Kapović 2010b: 57). ${ }^{38}$ All of this clearly shows that the standard, in our circumstances, was an "ideal" for a long time, and that it must be "neutral" to fulfil the purpose of its existence.

While some find it easier to speak close to the codified accentual norm, others find it difficult. It depends on the speaker's native idiom (speakers from Štokavian area find it easier than others, and those with a tonal system find it easier, or the only way possible, than those with the stress accent system). One frequently used method of teaching accents (Težak 1996) includes listening and imitating NeoŠtokavian speakers, which means their speech is indeed considered a norm which some find to be the ideal one. However, if we observe the codified norm from the Neo-Štokavians' perspective, we can no longer speak of an unattainable goal today, especially bearing in mind the way contemporary grammars approach accentuation rules and how stratified the standard is.

The following attitude was common among older linguists (in the period the amalgamation of Croato-Serbian language was imposed):

It seems pretty obvious how unfortunate it is that the usage norm differs from the codified norm in the same society and language collective. Such a discrepancy can only harm the language culture of that society and, consequently, its culture in general. This is why we cannot be indifferent if doubt arises as to whether the usus and codified norm coincide in some detail. (Brozović 2006 (1972-73): 28) ${ }^{39}$

38 "koji će općenito služiti kao koliko-toliko neutralno sredstvo sporazumijevanja" (Kapović 2010b: 57)

39 "Mislim da je prilično očito kako je veoma nepoželjno da se uporabna norma razlikuje od kodificirane norme u istome društvu i jezičnom kolektivu. Takav raskorak može samo škoditi jezičnoj kulturi toga društva, i time ujedno njegovoj kulturi uopće. Zato ne možemo biti ravnodušni ako se pokaže sumnja da li se u ovoj ili onoj pojedinosti podudaraju uporabna i kodificirana norma." (Brozović 2006 (1972-73): 28) 
Such attitudes are far from perceiving the codified norm as the ideal, on the contrary, they are striving toward a norm resembling usus.

In any case, it is assumed and expected for the usus norm to be presented at least in the linguistic practice of the circles and professions which use language, written and/or spoken, in the performance of their activities, meaning writers, teachers, presenters, reporters, actors, lawyers (particularly attorneys), etc. (Brozović, 2006 (1972-73): 28) (0 $^{40}$

The usus (though we can still talk about a usus norm) is developing today, building and becoming settled, and maintained through autonomous linguistic sentiment and prestige as the social convention of a particular collective. The problem is that today's codified norm is not reaching stability in a uniform manner, handbooks are not mutually consistent and they depart in relation to the linguistic community (even in the case of one where language is a professional matter and which attributes to itself the "ideal" which is not even the one that the majority of Štokavians are familiar with), and in relation to the system (imposed long ago, rather than selected) and its coherence (reduced to perseverance in implementing the defined rules without exceptions). In codifying the accentual norm, in addition to the principles of systemicity, the principle of standardization and of purposefulness must be kept in mind, so that the speaker is able to acquire and develop not only linguistic but also communication and pragmatic competences.

\section{Coloured accents}

An intertwining of linguistic levels on linguistic aspects and an intertwining of linguistic aspects (orthoepy and orthography) is best illustrated through the accentual norm. It is precisely in speech

\footnotetext{
40 "U svakom slučaju, pretpostavlja se i očekuje da će uporabna norma biti predstavljena bar u jezičnoj praksi krugova i zvanja kojima je jezik, pisani i(li) govoreni, ovakvo ili onakvo sredstvo njihove djelatnosti, dakle u pisaca, nastavnika, spikera, novinara, glumaca, pravnika (osobito odvjetnika) itd." (Brozović 2006 (1972-73): 28)
} 
that many open issues and many solutions at linguistic levels interact. ${ }^{41}$ We will demonstrate some of the open issues in a comparative analysis of manuals on the corpus of lexemes for colours. ${ }^{42}$

The reason orthography handbooks are addressed on the subject of orthoepy and accents is because they talk indirectly about pronunciation, and the yat is the best place to examine this ("a minor and isolated orthoepic-orthographic" issue). Where the alternant (morphoneme) is /ije/, orthography indicates the syllable duration as well as the place of stress, taking into consideration the rule that the stress cannot be preceded by a long syllable (therefore, neither can /ije/). The chapter "Shortening a syllable with the diphthong" in BFM's orthography indicates the following about syllable duration and shortening: "in all the syllables before the stress because, in Croatian standard language, the stress cannot be preceded by a long syllable, meaning also not by a diphthong" (BFM, 2000: 44) ${ }^{43} \cdot{ }^{44}$ All of this suggests how to read, for example, svijetlocrven and svjetlocrven, both of which are mentioned as options only in MH's orthography (in addition to a third option svijetlo crven if the meaning has not become "more obviously single-term"). Handbooks include examples such as prijestolonásljednīk (with ije in front of the stress) because, etymologically, this word was formed with the prefix prije(along with poslije- in the pre-stress position it is exempt from the shortening rule: prijepódnē and poslijepódnē), however, synchroni-

${ }^{41}$ For example, whether we will write and pronounce $s$ or $s a$ before the abbreviation "SAD" depends on the pronunciation: [ës-â-dê / esadê] so we choose the preposition $s$, and not $s a$; writing $i j e$ or $j e$ in masculine plural forms of one-syllable words depends on the constancy or changeability of the stress in the singular: snijêg - snijêga-snjëgovi, but lijêk - lijéka - lijékovi; double comparatives of one-syllable adjectives čistiji and čišci $i$, bjeliji and bjelji can be simplified using the rule "short stress - long suffix and long stress - short suffix": cìst - čistijī, bijêl - bjëljī; definite and indefinite forms of adjectives can actually be differentiated precisely using accent: crvèna and crvenāa žúta and $\check{z} u \hat{u} \bar{a}$; and a number of other general paradigmatic rules that inseparably connect grammar (sometimes even orthography) with the accent system.

42 VRH is the only dictionary which presents the double accentual form for the Turkish term boja: the old form boja and the one with the non-etymological ("kanovački") lengthening, frequent in the continental part - bója, and none of them presents the more recent form böja.

43 “(...) u svim slogovima ispred naglaska jer u hrvatskome književnome jeziku ne može ispred naglaska biti dugi slog, a prema tome ni dvoglasnik." (BFM 2000: 44)

44 Prefixes prije- and poslije- are not shortened in the pre-stress position. 
cally, in word formation, it need not be correlated with this but with prijestol/prijestolje, so incorrect spelling with je should be taken with reservation.

Contemporary dictionaries are prone to one solution (svijétlosmeđ), the one which is "systematic" in distribution (smëđ-smèđa-smèđe results in svijétlosmed - svijetlosmèđa - svijetlosmèđe), disregarding spoken manifestation and the rule of the shortening in the pre-stress position (svijetlosmèda, svijętlozèlen). HJS (also issued by the Institute for Croatian Language and Linguistics which also later published an orthography handbook and a dictionary in which it took a different approach to the issue at hand) is the only one that adopts a systematic shortening of the yat in the pre-stress position in the examples: svijétlomodar and svjetlòmodar, svijétloplàv and svjetlòplav, svijétlosmeđ and svjetlòsmed, svijétlozelen and svjetlozèlen, svijétložut (!) and svjetlöžut, however, the stressing of the interfix and preserving the defined distribution rule caused the proposed form to move away from the usus. ${ }^{45}$

Presently, the situation is as follows:

Table 3: Colours with a reflex of yat in more recent handbooks

\begin{tabular}{|c|c|c|c|c|c|c|}
\hline COLOURS & BFM & $\mathrm{MH} ; \mathrm{AS}^{46}$ & HP-IHJJ & HJP & ŠRHJ & VRH \\
\hline crno-bijel & - & - & crno-bijel & $\begin{array}{l}\text { cr̈no-bijel (!); }^{\text {cŕnobijēl }^{47}} \\
\end{array}$ & crno-bijêl & cr̀nobijē ${ }^{48}$ \\
\hline ml(i)ječnobijel & - (mliječan) & $\begin{array}{l}\text { mliječnobijel } \\
\text { and mlječnobijel, } \\
\text { mliječno bijel }\end{array}$ & $\begin{array}{l}\text { mlječnobijel and } \\
\text { mliječno bijel }\end{array}$ & $\begin{array}{l}\text { - (mlječan } \\
\text { and mliječni) }\end{array}$ & - (mliječni) & - (mliječan) \\
\hline sn(i)ježnobijel & $\begin{array}{l}\text { - (sniježan > } \\
\text { snježan) }\end{array}$ & $\begin{array}{l}\text { snježnobijel and } \\
\text { sniježnobijel, } \\
\text { sniježno bijel }\end{array}$ & $\begin{array}{l}\text { snježnobijel and } \\
\text { sniježno bijel }\end{array}$ & - (snjëžan) & - (snjëžan) & $\begin{array}{l}\text { - (snijêžan and } \\
\text { sniëžan) }\end{array}$ \\
\hline
\end{tabular}

45 I. Lupić referred to the handbook as "the scariest book on the standard in the last decade of the second millennium” (Lupić 2001: 89).

46 Anić-Silić's orthography handbook from 1986 contained compounds with the short reflex of yat (svjetlo-).

47 The explanation "bijel s crnom nijansom" (white with a shade of black) does not appear logical since tinting and shading of these two antonymous colours generates shades of grey.

48 In VRH, this colour refers to both black and white, meaning the word must be written with a hyphen. 


\begin{tabular}{|l|l|l|l|l|l|l|}
\hline COLOURS & BFM & MH; AS ${ }^{46}$ & HP-IHJJ & HJP & ŠRHJ & VRH \\
\hline sv(i)jetlosmed & $\begin{array}{l}\text { svijetlosmeđ } \\
\text { and svijetlo } \\
\text { smeđ }\end{array}$ & $\begin{array}{l}\text { svijetlosmeđ } \\
\text { and svjetlosmed, } \\
\text { svijetlo smeđ }\end{array}$ & $\begin{array}{l}\text { svjetlosmeđ and } \\
\text { svijetlo smeđ }\end{array}$ & $\begin{array}{l}\text { svjetlo- } \\
\text { (svijetlo-) }\end{array}$ & $\begin{array}{l}\text { svijétlosmeđ, } \\
\text { svijetlosmèđa }\end{array}$ & $\begin{array}{l}\text { vvijétlosmeđ, } \\
\text { svijetlosmèđa }\end{array}$ \\
\hline sv(i)jetloplav & $\begin{array}{l}\text { svijetloplav } \\
\text { and svijetlo } \\
\text { plav }\end{array}$ & $\begin{array}{l}\text { svijetloplav } \\
\text { and svjetloplav, } \\
\text { svijetlo plav }\end{array}$ & $\begin{array}{l}\text { svjetloplav and } \\
\text { svijetlo plav }\end{array}$ & $\begin{array}{l}\text { svjetlo- } \\
\text { (svijetlo-) }\end{array}$ & $\begin{array}{l}\text { svijétloplāv, } \\
\text { svijetlopláva }\end{array}$ & $\begin{array}{l}\text { svijétloplāv, } \\
\text { svijetlopláva }\end{array}$ \\
\hline sv(i)jetlozelen & $\begin{array}{l}\text { svijetlozelen } \\
\text { and svijetlo } \\
\text { zelen }\end{array}$ & $\begin{array}{l}\text { svijetlozelen } \\
\text { and svjetlozelen, } \\
\text { svijetlo zelen }\end{array}$ & $\begin{array}{l}\text { svjetlozelen and } \\
\text { svijetlo zelen }\end{array}$ & $\begin{array}{l}\text { svjetlo- } \\
\text { (svijetlo-) }\end{array}$ & $\begin{array}{l}\text { svijetlozèlen, } \\
\text { svijetlozelèna }\end{array}$ & $\begin{array}{l}\text { svijetlozèlen, } \\
\text { svijetlozelèna }\end{array}$ \\
\hline
\end{tabular}

Different writing options conditioned by meaning are not taken into consideration, e.g. ljubičastosmed (between purple and brown) and ljubičasto-smed (both purple and brown) because we are interested in the writing within the framework of one prosodic word. Orthography handbooks prescribe two options of writing adjectives compounded with an adverb, depending on whether we wish to emphasize the first part or not (tamno modar and tamnomodar). Maybe in the background of such a rule lies the issue of two accents (or the occurrence of a secondary accent) within one prosodic word or the occurrence of falling tone on the non-initial syllable. The idea was to solve this using space because emphasizing is achieved by stressing the part of the compound which is in the focus (támnomodar and tamnomödar), ${ }^{49}$ without unnecessary same-syllable metatonies or even white spaces. Emphasis as the reason for writing compounds separately was not mentioned in Babićs TR where he referred to those compounds as blends, many of which he described as "weak compound" that could therefore be pronounced with a pause and written as two words (TR 2002: 472). From the corpus of adjectives he used, Babić is evidently inclined toward emphasizing the first part of the compound and avoiding a falling tone on a non-initial syllable: svijêtloplāv, šljùvastoplāv, támnoplāv, támnosmēđ, támnosīv, támnožūt, fösfornožūt, but tamnozèlen, smaragdnozèlen (without violating the distribution rule). Anić took a completely different stance on such words in his article On the accent of compound words

49 Longer words usually get a secondary accent, either an "automatic" one (accentual echo achieved through expiratory force) or a "real" one (achieved through one of the four accents). 
in the Croato-Serbian language: ${ }^{50}$ "Of the two accents on a compound word, the one on the second part is certainly strong, whereas the secondary one (on the first part) can be pronounced with more or less force, meaning it can be so strong that it must be marked." (Anić 2009: 262 $)^{51}$ The juncture at the morpheme boundary in a compound carries "intensified semantic value" and is manifested as a pause.

On a smaller corpus, the corpus of colours, as pars pro toto, we can also see how the most recent dictionaries (which actually include a significant amount of content from the large colour corpus) approach the distribution rules and all the efforts to preserve the "systemicity" that imposes the idiom as an "abstract construct" rather than an actual realization of communication.

Table 4: The new dictionaries and the old systemicity

\begin{tabular}{|l|l|l|}
\hline COLOURS & ŠRHJ $^{52}$ & VRH $^{53}$ \\
\hline sv(i)jetloljubičast & Svijetloljùbičast $^{3}$ & svijetloljùbičast \\
\hline tamnosmeđ & támnosmeđ, tamnosmèđa & támnosmeđ, tamnosmèđa \\
\hline tamnoplav & támnoplāv, tamnopláva & támnoplāv, tamnopláva \\
\hline tamnoljubičast & támnoljubičast, támnoljubičasta & tamnoljùbičast, támnoljùbičasta \\
\hline tamnozelen & támnozelen, tamnozelèna & támnozelen, tamnozelèna \\
\hline maslinastosmeđ & mäslinastosmeđ, maslinastosmèđa & mäslinastosmeđ, maslinastosmèđa \\
\hline ljubičastosmeđ & ljübičastosmeđ, ljubičastosmèđa & ljubičastosmèđ, ljubičastosmèđa \\
\hline sivosmeđ & sïvosmeđ, sivosmèđa & sìvosmeđ, sivosmèđa \\
\hline modroljubičast & modroljùbičast & modroljùbičast \\
\hline sivomodar & - & sivomòdar \\
\hline ljubičastocrven & - & ljubičastocrven, ljubičastocrvena \\
\hline plavobijel & plävobijēl, plavobijéla & plävobijēl, plävobijéla \\
\hline sivobijel & sïvobijēl, sivobijéla & sìvobijēl, sivobijéla \\
\hline bjelosiv & bjëlosīv, bjelosíva & bjëlosīv, bjëlosīva \\
\hline
\end{tabular}

50 O akcentu složenica u hrvatskosrpskom jeziku

51 “Od dvaju akcenata na složenici nesumnjiva je silina onoga na drugom dijelu, dok sekundarni (na prvom dijelu) može biti izgovoren većom ili manjom silinom, odnosno može imati takvu silinu da se mora zabilježiti." (Anić 2009: 262)

52 The two bolded examples illustrate perfectly the two ways to avoid the falling tone on a non-initial syllable (by emphasizing the first part of the compound or by same-syllable metatony on the second part of the compound). The colour purple (with a short falling accent, ljübičast, in that dictionary) is used as an example. When it comes to the accent on the word for the colour purple in Croatian, HJS says it is a doublet (ljübičast and ljùbičast).

53 Examples that can be considered slips, because the dictionary is based on different rules, are bolded, although these examples (almost all of them) can be explained by pronunciation. 
HJS notes that tamno- is written without a hyphen in compound words (támnosiv, támnoplāv), and that colours with the prefix svijetlo- can also be pronounced with an accent on the second part (with metatony, svijétloplàv and svjetlòplav), and the real difference is not in the lexeme of the first part of the compound word but in the emphasis, utterance and context.

In addition to the open questions of distribution (the position of the falling accent is still strictly defined in some handbooks), colours and compounds also reveal what happens on a larger corpus of compounds when the doublet form is possible even in handbooks (it is equally a matter of the variability of the standard as in the first case). Today, the accent on the interfix, as a characteristic of the higher variety, is mentioned in those handbooks that are considered more prescriptive than others (e.g. ŠRHJ). With regard to compounds, HJS and RHJ-LZ are the most consistent of all handbooks in terms of adopting doublet forms with an accent on the initial syllable in the first position (which is certainly their greatest asset in presenting the accentual norm). The VRH dictionary is similar in this regard, but it is inconsistent when it comes to doublets. The way handbooks treat the accent on the interfix is precisely what makes a decisive difference between contemporary handbooks and represents the only step away from or toward the usus.

Table 5: The accent in compounds (with a interfix) in contemporary dictionaries ${ }^{54}$

\begin{tabular}{|l|l|l|l|l|l|l|}
\hline & AR & HJS & RHJ-LZ & HER, HJP & ŠRHJ & VRH \\
\hline plavokos & plavòkos & $\begin{array}{l}\text { plävokos and } \\
\text { plavòkos }\end{array}$ & $\begin{array}{l}\text { plävokos } \\
\text { (plavòkos) }\end{array}$ & plavòkos & plavòkos & $\begin{array}{l}\text { plävokos, } \\
\text { plavòkos }\end{array}$ \\
\hline crnokos & crnòkos & - & $\begin{array}{l}\text { cr̀nokos } \\
\text { (crnòkos) }\end{array}$ & crnòkos & crnòkos & crnòkos \\
\hline tamnokos & - & $\begin{array}{l}\text { tämnokos and } \\
\text { tamnòkos }\end{array}$ & - & tamnòkos & tamnòkos & $\begin{array}{l}\text { tàmnokos, } \\
\text { tamnòkos }\end{array}$ \\
\hline plavook & plavòok & $\begin{array}{l}\text { plävook and } \\
\text { plavòok }\end{array}$ & $\begin{array}{l}\text { plävook } \\
\text { (plavòok) }\end{array}$ & plavòok & plavòok & $\begin{array}{l}\text { plävook, } \\
\text { plavòok }\end{array}$ \\
\hline
\end{tabular}

54 Columns with a bolded heading contain a list of doublets designated as usus doublets by the authors. 


\begin{tabular}{|l|l|l|l|l|l|l|}
\hline & AR & HJS & RHJ-LZ & HER, HJP & ŠRHJ & VRH \\
\hline crnook & crnòok & $\begin{array}{l}\text { cr̀nook and } \\
\text { crnòok }\end{array}$ & $\begin{array}{l}\text { cr̀nook } \\
\text { (crnòok) }\end{array}$ & crnòok & crnòok & crnòok \\
\hline bjeloput(an) & bjelòputan & $\begin{array}{l}\text { bjëloput and } \\
\text { bjelòput }\end{array}$ & $\begin{array}{l}\text { bjëloputan } \\
\text { (bjelòputan) }\end{array}$ & $\begin{array}{l}\text { bjelòputan, } \\
\text { bjëloputan }\end{array}$ & bjelòput & $\begin{array}{l}\text { bjëloput, } \\
\text { bjelòput }\end{array}$ \\
\hline crnoput & crnòput & - & - & crnòput & - & crnòput \\
\hline tamnoput & tamnòput & $\begin{array}{l}\text { tämnoput and } \\
\text { tamnòput }\end{array}$ & $\begin{array}{l}\text { tämnoput } \\
\text { (tamnòput) }\end{array}$ & tamnòput & tamnòput & $\begin{array}{l}\text { tàmnoput, } \\
\text { tamnòput }\end{array}$ \\
\hline bjelobrad & - & $\begin{array}{l}\text { bjëlobrad and } \\
\text { bjelòbrad }\end{array}$ & $\begin{array}{l}\text { bjëlobrad } \\
\text { (bjelòbrad) }\end{array}$ & $\begin{array}{l}\text { bjelòbrad, } \\
\text { bjëlobrad }\end{array}$ & - & bjelòbrad \\
\hline crnobrad & crnòbrad & - & $\begin{array}{l}\text { cr̀nobrad } \\
\text { (crnòbrad) }\end{array}$ & crnòbrad & - & crnòbrad \\
\hline plavobrad & - & $\begin{array}{l}\text { plävobrad and } \\
\text { plavòbrad }\end{array}$ & - & - & - & $\begin{array}{l}\text { plävobrad, } \\
\text { plavòbrad }\end{array}$ \\
\hline plavokrvan & plävokr̄van & $\begin{array}{l}\text { plävokr̄van and } \\
\text { plavòkr̄van }\end{array}$ & - & $\begin{array}{l}\text { plävokr̄van, } \\
\text { plavòkr̄van }\end{array}$ \\
\hline crnomanjast & crnòmanjast & $\begin{array}{l}\text { crnòmanjast and } \\
\text { crnomànjast }\end{array}$ & $\begin{array}{l}\text { crnòmanjast } \\
\text { crnòmanjast }\end{array}$ & - & crnòmanjast & crnòmanjast \\
\hline
\end{tabular}

Grammar books are more inclined toward the accent on the interfix and in this sense they coincide with a higher standard variety. However, with the publication of the Silić-Pranjković grammar book and the fourth volume of the Academy's grammar book (NHKJ) in the first decade of the $21^{\text {st }}$ century, preference is given to usus and neutral forms of compounds with the accent on the initial syllable. It is unusual that all the contemporary grammars contain notes on the conversational form with a falling accent on a non-initial syllable of loanwords, but fail to systematically present forms with an accent on the initial syllable in compounds and to explain this phenomenon in more detail (which is actually the most systematic of all those mentioned casually, and which does not encroach on distribution rules). In Word Formation (Tvorba riječi), Babić pointed out that dictionaries and usage do not agree in the accentuation of suffixed compounds and that the placement of accent needs to be re-examined (TR 2002: 164). The following table shows the direction taken by handbooks in the $21^{\text {st }}$ century - they turned to the usus (i.e. stress placement according to the usus). 
Table 6: The accent on compounds (with an interfix) in contemporary grammars

\begin{tabular}{|c|c|c|c|c|}
\hline TR & HG & PHG & SP-GHJ ${ }^{55}$ & NHKJ \\
\hline $\begin{array}{l}\text { crnòkos } \\
\text { brzònog } \\
\text { kratkòrep } \\
\text { samòhran }\end{array}$ & $\begin{array}{l}\text { crnòkos } \\
\text { brzònog } \\
\text { kratkòdlak }\end{array}$ & $\begin{array}{l}\text { plavòkos } \\
\text { brzònog } \\
\text { gològlav } \\
\text { dugòvjek } \\
\text { šaròlik } \\
\text { mladòlik }\end{array}$ & - & $\begin{array}{l}\text { crnòkos } \\
\text { brzònog } \\
\text { dügoprst and dugòprst } \\
\text { krätkoglav and } \\
\text { kratkòglav } \\
\text { tämnoput and tamnòput }\end{array}$ \\
\hline $\begin{array}{l}\text { životopīs and životòpis; } \\
\text { kämenolōm and } \\
\text { kamenòlom } \\
\text { jezikòslōvlje } \\
\text { samòljüblje } \\
\text { domòljūblje } \\
\text { rödoljūblje } \\
\text { mesòžder } \\
\text { ljudòžder }\end{array}$ & $\begin{array}{l}\text { životopis and životòpis; } \\
\text { kàmenolom and } \\
\text { kamenòlom } \\
\\
\text { mesòžder } \\
\text { ljudòžder }\end{array}$ & - & \begin{tabular}{|l} 
Životopis \\
\\
jèzikoslōvlje \\
prìrodoslōvlje \\
sämoljūblje
\end{tabular} & $\begin{array}{l}\text { jèzikoslōvlje } \\
\text { prìrodoslōlle } \\
\text { samòljūblje and } \\
\text { sämoljūblje } \\
\text { mësožder } \\
\text { liüdožder and liudòžder }\end{array}$ \\
\hline
\end{tabular}

\section{Standard variety and competent speakers (exemplified by the speech of actors)}

Speakers we should listen to when we wish to hear standard speech/ pronunciation used to be considered (role) models, however, from that perspective, there might seem to be only one settled and homogeneous pronunciation for a particular standard language. In defining the standard as a specific idiom, autonomy and concreteness are questionable because we do not speak the standard language in its entirety, but instead we use its particular functional (sub)style (which also involves specific structures), and this implies different varieties. First of all, the speaker must be competent in the linguistic, communicational and pragmatic sense to be able to handle communication

55 Silić-Pranjković's grammar book does not contain enough accented adjectival compounds (the research was motivated by adjectives referring to colour), and the corpus of nouns also shows consistency (in terms of the manner of formation and the number of syllables), because grammar books can analyse rules comparatively, not individual examples. 
situations, recognize the context of the situation and adapt to other interlocutors. Selecting the most appropriate variety is subject to the communication norm (Škiljan 2000). If we look at the microstructure of the communication norm, exemplified by the accentual norm, the selection of a variety (perceptively and productively) comes down, first and foremost, to stress placement (thus also encompassing the rule of stress shift and the accent distribution rules).

The Croatian standard is not absolutely neutral (on account of its underlying basis to begin with), but it does achieve certain neutrality by being taught at schools and used in official situations. "Therefore, the speech of the presenters from the Croatian National Television is perceived as a more or less neutral standard and is not associated with any local vernaculars, regardless of how Štokavian the standard accent is and, as such, similar to the accent of organic Štokavian vernaculars." (Kapović 2010b: 68). ${ }^{56}$ It must be added that the neutrality is not enhanced by the presenters' speech (context of performance) nor by the fact that the Croatian standard language has been operating as the standard for a long time, but by the fact that organic Štokavian idioms intertwined with urban dynamic-accent idioms and other organic pronunciations have generated speakers (through education and environmental influence) whose variety resembles organic Štokavian ${ }^{57}$ mostly in terms of place of stress and partly in terms of accent inventory and post-tonic syllable quantity. All of this, together with the cultivation of speech or neutral intonation, certainly affects the impression of the speaker/presenter as a neutral speaker.

On the e-lektira website, some ten younger actors read works from the school list of Croatian and world literature. The selection included about 130 minutes of spoken text (authored by the brothers Grimm,

56 "Stoga se govor spikerâ s HRT-a primjerice doživljava kao koliko-toliko neutralan standard i ne povezuje ga se s lokalnim govorima, koliko god standardni naglasak bio štokavski i time nalik naglasku organskih štokavskih govora." (Kapović 2010b: 68)

57 In the research by Vlašić Duić and Pletikos Olof (2018), an educated speaker from the Kajkavian area (who used the four-accent system in her speech) living in an environment where a predominantly dynamic system is used and lengths are reduced (Zagreb), was assessed as the most exemplary speaker. 
C. Perrault, I. Brlić-Mažuranić, J. Kozarac) performed by six actors ${ }^{58}$ (two female and four male voices), three of whom were native speakers of the stress accent vernacular and three were speakers from the pitch accent area. ${ }^{59}$ The listening was focused on the place of stress (on the words in the falling intonation units), the duration of the post-tonic syllable and the accent inventory. The presumption was that actors (as educated speakers) strove toward a higher standard variety in reading texts from the school reading list, especially in a situation of "supervised production" (reading). Two papers served as the starting point in listening to the speakers' inventory: Škarićs chapter in GOHKJ (2007) where he claimed that Neo-Stokavians used a so-called accepted type of pronunciation, without a short rising accent and length, and the paper by Vlašić Duić and Pletikos Olof (2018) who ascertained the presence of rising accents (more often short rising than long rising accents) in the speech of educated speakers of a stress accent vernaculars.

In e-lektira, in case of both groups of speakers, it was noticed that one system influenced the other: educated speakers of a stress accent vernaculars have a five-accent system, and speakers of a pitch accent vernacular (probably under the influence of larger milieus) sometimes pronounce a short falling accent in the position of some other expected accent. Speakers with the stress accent system, to whom we listened, made no mistakes in the place of stress, but the tone was not automatic (ötvorena, räzgazim, mäjstoričina, vëčerati, zäprljana, üplašila, ne pöbjegne). Speakers of pitch accent vernaculars more

58 Dora Lipovčan (Grimm: Pepeljuga - Cinderella; Grimm: Crvenkapica - Little Red Riding Hood; C. Perrault: Vile - The Fairies); Urša Raukar (I. Brlić-Mažuranić: Čudnovate zgode šegrta Hlapića - The Brave Adventures of Hlapitch); Zoran Čubrilo (V. Novak: Posljednji Stipančići - The Last of the Stipančić Family); Nikša Marinović (Grimm: Vuk i sedmero jaradi - The Wolf and Seven Little Goats; Grimm: Trnoružica - Sleeping Beauty; Grimm: Snjeguljica - Snow White; I. Brlić-Mažuranić: Basne Fables); Zvonimir Bulaja (Grimm: Bremenski gradski svirači - Town Musicians of Bremen); Marijana Matoković (J. Kozarac: Tena)

59 The assessment of the starting idiom is based on data offered by the actors' and actresses' CVs on their websites (place of birth, where they went to school and where they live(d)). It was noticed that the reading was sometimes assigned to actors based on their origin. For example, M. Matoković, an actress from Požega, offered a wonderful rendition of Tena and Đuka Begović. 
often shifted the stress to the proclitic, particularly when pronouncing pronouns. In case of both groups of speakers, the shift occurred more often in dialogues and when archaic style was employed (the same speaker of the pitch accent language said: $u$ küći : ù kući; $u$ šümu : ùu šumu).

The research showed that the neutral variety of the standard is characterised by the stability of the stress shift (even in prosodic words with pronouns, outside the characters' dialogue), except in cases of verb negation (and when it is common sä mnōm, nâ nj, ná me, etc.). The falling accent on a non-initial syllable is quite common in the genitive plural and in compounds (brežûljaka/brežûljāka, patûljaka/ patûljāka, Trnorüžica, dijamänata). Post-tonic length is more frequent in speakers of pitch accent vernaculars, and in just one instance, in a prosodic word, most often after an accent on a word-medial syllable, where the length is organic, as well as after short accents, and after long accents in the position of the morphological sign of the plural. When it comes to speakers of the stress accent vernaculars, length is present on originally long syllables, which is a consequence of adapting the stress placement to a higher variety.

Table 7: Accent system in e-lektira audio records (examples of six speakers)

\begin{tabular}{|c|c|c|c|c|c|c|}
\hline \multirow[b]{2}{*}{$\begin{array}{l}\text { speakers } \\
\\
\text { starting } \\
\underline{\text { stress }} \\
\text { accent } \\
\text { system }\end{array}$} & \multicolumn{2}{|c|}{ distribution rules } & \multicolumn{2}{|l|}{ post-tonic length } & \multicolumn{2}{|c|}{$\begin{array}{l}\text { pitch and stress accent system } \\
\text { intertwined }\end{array}$} \\
\hline & $\begin{array}{l}\text { pò njega } \\
\text { zà njīh } \\
\text { nà njīh } \\
\text { zà njīm } \\
\text { nà tō } \\
\text { ù njoj } \\
\text { öd sebe } \\
\text { köd kuće } \\
\text { ü Rīm } \\
\text { nè skreći } \\
\text { nè čuješ } \\
\text { nè nāđe } \\
\text { nè može }\end{array}$ & $\begin{array}{l}\text { i vî } \\
\text { u tê } \\
\text { na svôj } \\
\text { na njû } \\
\text { po njû } \\
\text { na tëbe } \\
\text { sa söbom } \\
\text { oko sëbe } \\
\text { pod } \\
\text { nëbom } \\
\text { kod küće } \\
\text { do nëba } \\
\text { do mrâka } \\
\text { od râda } \\
\text { na könja } \\
\text { na ülici }\end{array}$ & $\begin{array}{l}\text { kod báke kod küće } \\
\text { od küće } \\
\text { od vöde } \\
\text { iz pöstelje } \\
\text { žënom } \\
\text { do raména } \\
\text { iz rätova } \\
\text { pôđe } \\
\text { odbójnost } \\
\text { känonik } \\
\text { drägulj } \\
\text { ösjećaj }\end{array}$ & $\begin{array}{l}\text { zàbrāni } \\
\text { hälīina } \\
\text { kämēnje } \\
\text { uspròtīvi } \\
\text { se } \\
\text { nè nāđe } \\
\text { ràzrāsla } \\
\text { talijānski } \\
\text { postòlār } \\
\text { genèrāl }\end{array}$ & $\begin{array}{l}\text { Hläpić, Mr̈konja, } \\
\text { läkat, döbro, } \\
\text { žëna, mägarca, } \\
\text { šěšir, } \\
\text { žëlju, sëstre, } \\
\text { cìpele, bïskup, } \\
\text { sljepöćom, lëća, } \\
\text { u ränu, u lice, do } \\
\text { ströpa, od sükna, } \\
\text { u nëdjelju, za } \\
\text { svöga, radiönicu, } \\
\text { mǐševi, zëlene, } \\
\text { od cřvena könac, } \\
\text { tïho, koläča, } \\
\text { vìna, prevëlika, } \\
\text { poklöni mu se, } \\
\text { na ramëna }\end{array}$ & $\begin{array}{l}\text { Crvènkapica } \\
\text { uspròtīvi se } \\
\text { premalèna } \\
\text { ràzrāsla } \\
\text { làtīnski } \\
\text { talijānski } \\
\text { vòlio } \\
\text { Màrije } \\
\text { mâjke, krîvo, } \\
\text { Mârko, bîva, } \\
\text { nôž, grâne, } \\
\text { lijêpa, glâs, } \\
\text { sât, krâsnu, } \\
\text { sâm }\end{array}$ \\
\hline
\end{tabular}




\section{KNJIŽEVNI JEZIK 31, 2020. (115-149]}

\begin{tabular}{|c|c|c|c|}
\hline speakers & distribution rules & post-tonic length & $\begin{array}{l}\text { pitch and stress accent system } \\
\text { intertwined }\end{array}$ \\
\hline & $\begin{array}{l}\text { na krüšku } \\
\text { na glâvu } \\
\text { za } \\
\text { crijêcécm } \\
\text { za rûku } \\
\text { po vödu } \\
\text { u kût } \\
\text { u svijêt } \\
\text { u söbi } \\
\text { u snü } \\
\text { u škôlu } \\
\text { u šùmu } \\
\\
\text { dijamänata } \\
\text { Valpûrga } \\
\text { patrîijia }\end{array}$ & & $\begin{array}{l}\text { putovánje, } \\
\text { udivljénje, } \\
\text { skrívala, } \\
\text { rúgali, nijésu, } \\
\text { s njíme, níje, } \\
\text { dóđite, } \\
\text { ne bijǎše, } \\
\text { trijébiti, } \\
\text { sprémaše, } \\
\text { u tórbu, } \\
\text { púku, } \\
\text { prózor, } \\
\text { Klementína } \\
\\
\text { ötvorena } \\
\text { räzgazim } \\
\text { mâjstoričina } \\
\text { večcerati } \\
\text { zäprljana } \\
\text { üplašila } \\
\text { ne pöbjegne }\end{array}$ \\
\hline
\end{tabular}

\begin{tabular}{|c|c|c|c|c|c|c|}
\hline speakers & distributic & on rules & post-tonic le & & $\begin{array}{l}\text { pitch and st } \\
\text { intertwined }\end{array}$ & cent system \\
\hline $\begin{array}{l}\text { starting } \\
\text { pitch } \\
\text { accent } \\
\text { system }\end{array}$ & $\begin{array}{l}\text { nà tō } \\
\text { ù tō } \\
\text { ì tō } \\
\text { zà nās } \\
\text { zà njōmm } \\
\text { ìz njē } \\
\text { ù njē } \\
\text { ù njū } \\
\text { ù tebe } \\
\text { ù tāj } \\
\text { nà meni } \\
\text { okò njega } \\
\text { prëd } \\
\text { Bogom } \\
\text { ù šumu } \\
\text { ì drugī }\end{array}$ & $\begin{array}{l}\text { na njëmu } \\
\text { u sëbi } \\
\text { u näšū } \\
\text { u tëbe } \\
\text { kod nâs } \\
\text { kod tëbe } \\
\text { za njû } \\
\text { uza njû } \\
\text { oko njê } \\
\text { za nögu } \\
\text { za râd } \\
\text { za lôv } \\
\text { za kösu } \\
\text { na psä } \\
\text { na br̈du } \\
\text { na grôblje }\end{array}$ & $\begin{array}{l}\text { svèčanost } \\
\text { budúćnost } \\
\text { järad } \\
\text { vidik } \\
\text { ökvir } \\
\text { pôđu } \\
\text { nâdu } \\
\text { dřšće } \\
\text { ümrem } \\
\text { vrijédi } \\
\text { od svíle } \\
\text { žène } \\
\text { pred cr̂nom } \\
\text { glávom } \\
\text { bójom } \\
\text { za djècom } \\
30 \text { gödina }\end{array}$ & 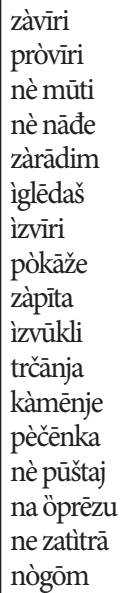 & $\begin{array}{l}\text { kïv } \\
\text { po trinju } \\
\text { pïvi } \\
\text { mïtva } \\
\text { u zëmlji } \\
\text { vikkne } \\
\text { živo } \\
\text { djëte } \\
\text { kölala } \\
\text { živìca } \\
\text { približio se }\end{array}$ & $\begin{array}{l}\text { progùtao } \\
\text { okrúgao } \\
\text { skakùtala } \\
\text { obàmrla } \\
\text { svakìdanjī } \\
\text { svakìdašnje }\end{array}$ \\
\hline
\end{tabular}

60 In this second column, there is nothing to write for these speakers because their entire starting system is here, but we have listed a few examples that show that, in choosing between high and neutral system varieties, these speakers sometimes choose the forms closer to a higher variety. 


\begin{tabular}{|c|c|c|c|c|c|}
\hline \multirow[t]{2}{*}{ speakers } & \multicolumn{2}{|c|}{ distribution rules } & \multicolumn{2}{|c|}{ post-tonic length } & $\begin{array}{l}\text { pitch and stress accent system } \\
\text { intertwined }^{60}\end{array}$ \\
\hline & $\begin{array}{l}\text { në bijāše } \\
\text { nè pūštaj } \\
\text { në bī } \\
\text { nè } \\
\text { mogaše } \\
\text { nè nāđe } \\
\text { nè mūti }\end{array}$ & $\begin{array}{l}\text { u mâjke } \\
\text { u nögu } \\
\text { u šümu } \\
\text { u vîs } \\
\text { u snijêg } \\
\text { u söli } \\
\text { u dân } \\
\text { u pïst } \\
\text { u öči } \\
\text { po kâp } \\
\text { kod küćce } \\
\text { brežûljaka } \\
\text { patûljaka } \\
\text { Trnorüžica } \\
\text { od patrîcija }\end{array}$ & $\begin{array}{l}\text { Bògova } \\
\text { prekrivenih } \\
\text { pöčešljanog } \\
\text { drügoga } \\
\text { nâjmlađe } \\
\text { nâjmanju }\end{array}$ & $\begin{array}{l}\text { iz vòdē } \\
\text { dánā } \\
\text { do vrátā } \\
\text { dvorànē } \\
\text { dërēš } \\
\text { rëknē } \\
\text { svìrāč } \\
\text { divān } \\
\text { nâjljepšī }\end{array}$ & \\
\hline
\end{tabular}

All of this leads to the conclusion that the characteristics of the speech rendered by speakers with automatic rising and falling tones are as follows: stability of the stress shift (except in verb negation and a few pronouns), standard stress placement (within a written word), falling tone in the previously described common cases on a non-initial syllable, post-tonic lengths reduced to one - the original one after short accents, and short and long syllabic $r$. All these characteristics make up a system we refer to as neutral. It can also be concluded that the actors who were speakers of stress accent vernaculars came closer to the pitch accent system pronunciation than the linguists (whose speech was analysed by Vlašić Duić and Pletikos Olof). It must be borne in mind at the same time that the type of text that was read (literary art) certainly required more adaptability from the speakers.

\section{Final thoughts}

Many linguists view the Croatian accentual norm at the beginning of the $21^{\text {st }}$ century somewhat differently than in the $20^{\text {th }}$ century. To begin with, they approach open issues differently. We recognize three contemporary branches: the conservative one - disinclined to changing distribution rules (e.g. in the most recent dictionaries), the 


\section{KNJǏEEVI JEZIK 31, 2020. (115-149]}

moderate one - which corrects the accent rules in one part of the system (e.g. in contemporary grammar books) and the revolutionary one - which questions the entire accent system, takes into consideration both the stress and pitch accent systems and views the standard through the prism of variety (such ideas have not made it to any handbook yet).

Researching the usus and properties of the speech of competent speakers is becoming an increasing challenge because public speech is not homogeneous; pitch and stress accent systems intertwine in public discourse. In this paper, actors and actresses demonstrated speech in "controlled conditions" and showed that the features of the speech of actors/actresses can be considered to belong to the neutral variety of the standard language. Almost all of these features were also mentioned in contemporary grammar books.

In the reading of literary works (written in the standard language), we expected a high variety (more stress shifts in the proclisis, consistent post-tonic lengths, consistent distribution rules), but it seems that for the younger generation of actors/actresses, the neutral variety of the pitch accent system is already "high" enough and distant enough from the stress accent system for them to use it (quite reasonably) in public performance.

\section{References}

Anić, Vladimir (1968): "O jednom akcenatskom procesu u različitim službama književnog jezika”, Jezik 16/3, 84-89.

Anić, Vladimir (2009): Naličje kalupa - Sabrani spisi, Disput, Zagreb.

Anić, Vladimir; Silić, Josip (1986): Pravopisni priručnik hrvatskoga ili srpskoga jezika, Školska knjiga - SN Liber, Zagreb.

Barić, Eugenija i dr. (1979): Priručna gramatika hrvatskoga književnog jezika, Školska knjiga, Zagreb.

Brabec, Ivan; Hraste, Mate; Živković, Sreten (1965): Gramatika hrvatskosrpskoga jezika, Školska knjiga, Zagreb. 
Brozović, Dalibor (2006): Neka bitna pitanja hrvatskoga jezičnog standarda, Školska knjiga, Zagreb.

Delaš, Helena (2006): "Proučavanje hrvatske prozodije u 20. stoljeću", in: Samardžija, M.; Pranjković, I. (eds) Hrvatski jezik u XX. st., Matica hrvatska, Zagreb, 71-89.

Jonke, Ljudevit (1965): Književni jezik u teoriji i praksi, Znanje, Zagreb.

Kalogjera, Damir (1998): "Nezaobilaznost normi (norma) i kritika norme", in: Badurina, L.; Pritchard, B.; Stolac, D. (eds) Jezična norma $i$ varijeteti, Hrvatsko društvo za primijenjenu lingvistiku, Zagreb - Rijeka, 241-249.

Kapović, Mate (2007): "Hrvatski standard - evolucija ili revolucija? Problem hrvatskoga pravopisa i pravogovora", Jezikoslovlje 8/1, $61-76$.

Kapović, Mate (2010a): “O tobožnjoj neutralizaciji kratkih naglasaka u hrvatskom", Croatica et Slavica Iadertina 6/6, 47-54.

Kapović, Mate (2010b): Čiji je jezik?, Algoritam, Zagreb.

Katičić, Radoslav (1995): "Načela standardnosti hrvatskoga jezika", Jezik 43/5, 175-182.

Lupić, Ivan (2001): “Preskriptivna akcentologija i hrvatski standardni jezik”, Kolo XI/1, 85-134.

Martinović, Blaženka (2017): "Kodifikacija hrvatske naglasne norme (ili kako naši priručnici govore)", Rasprave: časopis Instituta za hrvatski jezik i jezikoslovlje 43/1, 95-106.

Mićanović, Krešimir (2006): Hrvatski s naglaskom, Disput, Zagreb.

Pranjković, Ivo (2001): “Za demokratizaciju hrvatske ortoepske norme", in: Jezik i demokratizacija, Radovi 12, Institut za jezik, Sarajevo, 299-306.

Pranjković, Ivo (2010): Ogledi o jezičnoj pravilnosti, Disput, Zagreb. 


\section{KNJIŽEVNI JEZIK 31, 2020. (115-149)}

Samardžija, Marko (1999): "Norme i najnovije promjene u hrvatskome jeziku”, Zaprešićki godišnjak 1998. Matica hrvatska Zaprešić, Zaprešić, 327-340.

Silić, Josip (2006): Funkcionalni stilovi hrvatskoga jezika, Disput, Zagreb.

Škarić, Ivo (2006): Hrvatski govorili!, Školska knjiga, Zagreb.

Škarić, Ivo; Lazić, Nikolaj (2002): "Vrijednosni sudovi o hrvatskim naglascima”, Govor XIX/1, 5-34.

Škarić, Ivo; Škavić, Đurđa; Varošanec Škarić, Gordana (1995): “Kako se naglašavaju posuđenice", Jezik XLIII/4, 129-138.

Škiljan, Dubravko (2000): Javni jezik, Izdanje Antibarbarus, Zagreb.

Težak, Stjepko (1996): Teorija i praksa nastave hrvatskoga jezika 1, Školska knjiga, Zagreb.

Vlašić Duić, Jelena; Pletikos Olof, Elenmari (2018): "Naglasci u govoru hrvatskih jezikoslovaca", Jezici $i$ kulture $u$ vremenu $i$ prostoru VII/1, Novi Sad, 255-265.

Vukušić, Stjepan (1984): Nacrt hrvatske naglasne norme na osnovi zapadnog dijalekta, Istarska naklada, Pula.

\section{Sources and abbreviations}

AS: Anić, Vladimir; Silić, Josip (2001): Pravopis hrvatskoga jezika, Novi Liber, Zagreb.

BFM: Babić, Stjepan; Finka, Božidar; Moguš, Milan (2000): Hrvatski pravopis, Školska knjiga, Zagreb.

E-lektira, e-dokument: www.lektire.skole.hr.

GOHKJ: Babić, Stjepan et al. (2007): Glasovi i oblici hrvatskoga književnoga jezika, NZ Globus, Zagreb.

HER: Jojić, Lj.; Matasović, R. (eds) (2002): Hrvatski enciklopedijski rječnik, Novi Liber, Zagreb. 
HG: Barić, Eugenija et al. (2005): Hrvatska gramatika, Školska knjiga, Zagreb.

HJP: Hrvatski jezični portal, e-izvor: www.hjp.znanje.hr.

HJS: Barić, Eugenija i dr. (1999): Hrvatski jezični savjetnik, Institut za hrvatski jezik i jezikoslovlje, Zagreb.

HŠG: Hudeček, Lana; Mihaljević, Milica: Hrvatska školska gramatika, Institut za hrvatski jezik i jezikoslovlje, e-izdanje: www.gramatika. hr.

HP-IHJJ: Jozić, Ž. (ed.) Hrvatski pravopis, Institut za hrvatski jezik i jezikoslovlje, e-izvor: www.pravopis.hr.

MH: Badurina, Lada; Marković, Ivan; Mićanović, Krešimir (2007): Hrvatski pravopis, Matica hrvatska, Zagreb.

NHKJ: Vukušić, Stjepan; Zoričić, Ivan; Grasselli Vukušić, Marija (2007): Naglasak u hrvatskome književnom jeziku, Globus, Zagreb.

PHG: Raguž, Dragutin (1997): Praktična hrvatska gramatika, Medicinska naklada, Zagreb.

PPGO: Babić, Stjepan et al. (1991): Povijesni pregled, glasovi i oblici hrvatskoga književnog jezika, HAZU - Globus, Zagreb.

RHJ-LZ: Šonje, J. (ed.) (2000): Rječnik hrvatskoga jezika, Leksikografski zavod "Miroslav Krleža", Zagreb.

SP: Silić, Josip; Pranjković, Ivo (2005): Gramatika hrvatskoga jezika, Školska knjiga, Zagreb.

ŠGHJ: Ham, Sanda (2017): Školska gramatika hrvatskoga jezika, Školska knjiga, Zagreb.

ŠRHJ: Birtić, M. et al. (eds) (2012): Školski rječnik hrvatskoga jezika, Institut za hrvatski jezik i jezikoslovlje - Školska knjiga, Zagreb:

TB: Težak, Stjepko; Babić, Stjepan (2000): Gramatika hrvatskoga jezika, Školska knjiga, Zagreb. 
TR: Babić, Stjepan (2002): Tvorba riječi u hrvatskome književnome jeziku, NZ Globus - HAZU, Zagreb.

VA: Anić, Vladimir (1998): Rječnik hrvatskoga jezika, Novi Liber, Zagreb.

VA-ŠRHJ: Anić, Vladimir (2015): Školski rječnik hrvatskoga jezika, Novi Liber - Znanje, Zagreb.

VRH: Jojić, Lj. (ed.) (2015): Veliki rječnik hrvatskoga standardnog jezika, Školska knjiga, Zagreb.

\section{Hrvatska naglasna norma na početku 21. stoljeća (od teorije do prakse i natrag)}

Sažetak: Hrvatska naglasna norma u stalnome je previranju. Njezinu stabilnost priječe, prije svega, dvije silnice, koje se isprepleću: narav naglasne norme koja pripada govoru (dinamičnoj veličini, individualnome) te nesuglasje među jezikoslovcima što od ostvaraja zapisati i propisati (u stalnome prepletu udarnoga i visinskoga naglasnog sustava). Suvremena se naglasna norma iščitava iz neortoepskih priručnika, tj. iz gramatika, rječnika, savjetnika (što dodatno otežava bistrenje ortoepske stvarnosti). Komparativno ćemo analizirati kako, primjerice, suvremeni priručnici pristupaju "promjenljivosti naglaska", kako u tvorbi riječi prilaze silaznome naglasku izvan početnoga sloga, kako zanaglasnim dužinama, kako dvojbama leksičkoga naglaska i sl. Gramatike i rječnici različito pristupaju otvorenim pitanjima i ovaj rad nudi pregled (sustavnih i nesustavnih) rješenja koja nam donose jezikoslovci danas, $s$ nakanom da se prikaže dinamika kodeksa (koji nosi etiketu "konzervativnoga" i "začahurenoga"). Pomaci se u suvremenoj normi zatim uspoređuju s uzusnim pojavama, i to na primjeru jednoga užega govornoga korpusa - govora glumaca. Jezikoslovci, naime, u svojim ortoepskim istraživanjima posežu za govorom spikera na radiju i televiziji, za govorom jezikoslovaca u radijskim i televizijskim specijaliziranim 
emisijama, za govorom studenata kroatistike ili fonetike, govorom nastavnika hrvatskoga jezika i sl., a odnedavno se tomu nizu mogu pribrojiti i zvučni zapisi glumaca koji čitaju lektiru (MP3 formati dostupni na: www.lektire.skole.hr). Spikeri, profesori i glumci oduvijek su u definiciji kompetentnoga govornika standardnoga jezika pa je osluškivanje njihova govora $u$ opisivanju i/ili propisivanju ono na čemu počiva gotovo svako ortoepsko promišljanje. Budući da taj suvremeni (iz)govor (e-lektira) još uvijek nije jezično/ortoepski analiziran i valoriziran te da je podastrt onima koji uče i osluškuju govorne vrednote na takvim predlošcima, rad se okreće korpusu s ciljem iščitavanja osnovnih značajka izgovora. Analiziran je izgovor proznih tekstova pisanih standardnim jezikom ili prevedenih na standardni jezik. Posebna se pozornost skreće naglasku (mjestu naglaska i proklizi) i govornoj riječi. Izdvojene značajke izgovora (posebice s obzirom na naglasnu normu) uspoređuju se s onima koje su propisane u priručnicima. Na koncu se bistre one uzusne naglasne značajke koje suvremeni kodeks uzima $\mathrm{u}$ obzir te one koje se sustavno zanemaruju u suvremenome propisivanju.

Ključne riječi: kodeks, uzus, naglasak, e-lektira

Author's statement on the absence of conflicts of interest and compliance with general codes of ethics: The author confirms that there is no actual or potential conflict of interest related to this text and that the text is written in accordance with the codes of ethics according to the recommendations of COPE (Committee of Publishing Ethics). 